\title{
A case: Acute hepatitis associated with herbal (Teucrium chamaedrys) ingestion
}

\section{Bitki çayı (Teucrium chamaedrys) alımına bağlı gelișen bir akut hepatit olgusu}

\author{
Onur URAL ${ }^{1}, \quad$ Özgür SATILMIŞ², Gaye URAL ${ }^{3}, \quad$ Nebahat Dikici ${ }^{1}$
}

\section{ÖZET}

Türkiye'de bitkisel tedavilere bağı toksik bulgulara pek sık rastlanmamaktadır. Olgumuz 33 yașında bir bayan hastadır. Sarılık șikayeti ile bașvuran olgunun yaklașık iki haftadır, her gün Teucrium chamaedrys bitkisini içeren bir çayı aldığı öğrenilmiștir. Hastada akut ikterik hepatit bulguları saptanmış ve akut hepatit yapabilecek bașka bir neden tespit edilememiștir. $T$. chamaedrys alımı sonlandırılıp takip edilen hastada klinik iyileșme izlenmiș ve yaklașık dokuz hafta içinde serum bilirubin, aminotransferaz, alkalen fosfataz düzeyleri normal sınırlara düșmüștür. Bu olgu T. chamaedrys alımının akut ikterik hepatite neden olabileceği, klinik olarak akut viral hepatitleri taklit edebileceği ve bitkisel tedavilerin genel olarak kabul edildiği kadar güvenli olmadığını göstermektedir.

Anahtar Sözcükler: Bitkisel tedavi, Teucrium chamaedrys, hepatit

\section{ABSTRACT}

Herbal medicine toxicity has been infrequently reported in Turkey. Our case describes a 33- year-old woman who applied with jaundice. She acknowledged that she was taking daily a tea containing the plant Teucrium chamaedrys for two weeks. It was determined she had symptoms of acute icteric hepatitis. Other causes of acute hepatitis were excluded. After $T$. chamaedrys was not taken anymore by the patient, she recovered clinically and her serum bilirubin, aminotransferases and alkaline phosphatase values returned to normal levels within 9-weeks. This case suggests that $T$. chamaedrys intake may cause acute icteric hepatitis which might clinically mimic acute viral hepatitis, and it shows that herbal medicines are not as safe as they have been generally assumed.

Key Words: Herbal treatment, Teucrium chamaedrys, hepatitis

\footnotetext{
'Selçuk Üniversitesi, Selçuklu Tıp Fakültesi, Enfeksiyon Hastalıkları ve Klinik Mikrobiyoloji Ad, KONYA

${ }^{2}$ Çankırı Devlet Hastanesi, Enfeksiyon Hastalıkları ve Klinik Mikrobiyoloji Kliniği, ÇANKIRI

${ }^{3}$ Konya Numune Hastanesi, Enfeksiyon Hastalkları ve Klinik Mikrobiyoloji Kliniği, KONYA

İletişim/Corresponding Author: Onur URAL

Selçuk Üniversitesi, Selçuklu Tıp Fakültesi, Enfeksiyon Hastalıkları ve Klinik Mikrobiyoloji Ad, KONYA Geliş Tarihi / Received : 04.12.2010

Tel : +903322415000/40128_E-posta/E-mail : onurural64@yahoo.com

Kabul Tarihi / Accepted : 24.06.2011

DOI ID : 10.5505/TurkHijyen.2011.05900

Ural O, Satılmıș Ö, Ural G, Dikici N. A case: Acute hepatitis associated with herbal (Teucrium chamaedrys) ingestion. Turk Hij Den Biyol Derg, 2011 ; 68 (3): $135-8$.
} 


\section{INTRODUCTION}

Herbal remedies are becoming increasingly popular with the public as they are perceived as being beneficial, free of side effects, and complementary to Western medicines (1). To show that germander (Teucrium chamaedrys), a herbal medicine used to facilitate weight loss, might be hepatotoxic and to delineate the nature of the injury there have been a number of reports of hepatic toxicity involving different herbal products (2). Clinical and experimental studies have consistently incriminated the medicinal plant germander (Teucrium chamaedrys L.) in epidemic and sporadic cases of liver diseases (3). We present a case of acute hepatitis after ingestion of herbal tea over a period of several weeks. Among the plants consumed was T. chamaedrys. The hepatitis resolved after the intake of the herbal tea was stopped.

\section{CASE}

A 33-year-old woman who started daily consumption of a tea containing the plant T.chamaedrys L. developed after two weeks an acute icteric hepatitis-like illness (Figure 1).

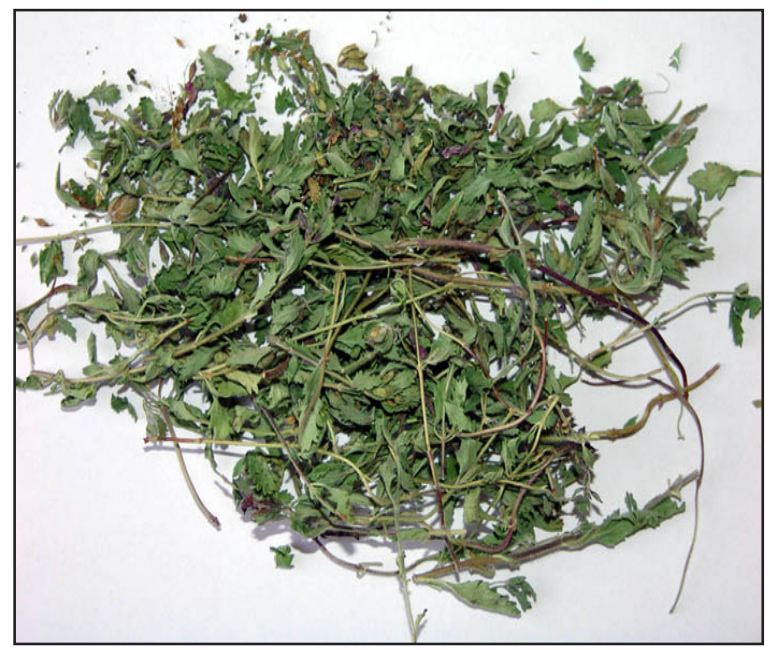

Figure 1. Teucrium chamaedris
The patient reported weight loss which was the result she hoped to achieve by the use of the herbal tea. She was admitted to our clinic with acute icteric hepatitis, and had no past medical history of hepatitis. Anorexia, nausea, vomiting, malaise appeared at her admission to hospital for ten days before admission at the clinic. The patient also noticed skin and sclera icteric hyperpigmentation and hyperpigmentation of her urine for five days. She denied taking any drugs orally or intravenously and also denied alcohol abuse. However admitted using a herbal tea which appears to contain Teucrium chamaedry L. she discontinued the use of the tea after her admission. Physical examination showed skin and sclera icteric hyperpigmentation and abdominal tenderness, hepatomegaly $2-3 \mathrm{~cm}$. The patient had no sign of chronic liver diseases. Laboratory values revealed; alanine aminotransferase (ALT) 539 IU/l (normal 14$54 \mathrm{IU} / \mathrm{l}$ ), aspartate aminotransferase (AST) $250 \mathrm{IU} / \mathrm{l}$ (normal 10-41 IU/l), gamma-glutamyltransferase (GGT) 40 IU/l (normal 7-50 IU/l), alkaline phosphatase (ALP) 177 IU/I (normal 40-150 IU/l), total bilirubin $2.5 \mathrm{mg} / \mathrm{dl}$ (normal 0.4-1.4 mg/dl), conjuguated bilirubin $0.96 \mathrm{mg} / \mathrm{dl}$ (normal $0.1-0.5 \mathrm{mg} / \mathrm{dl}$ ), and triglycerides $74 \mathrm{mg} / \mathrm{dl}$ (normal $40-200 \mathrm{mg} / \mathrm{dl}$ ). The peripheral leukocyte count increased to $11.8 \times 109 / \mathrm{L}$ with $7 \%$ eosinophils (normal, $<3 \%$ eosinophils). Other laboratory tests, including a serum urea nitrogen, creatine, glucose, electrolytes, total protein and albumin were normal. Coagulation studies were also normal. Serum hepatitis B surface antigen (HBsAg), antibody to hepatitis B surface antigen (anti-HBs), antibody to hepatitis B core antigen (anti- HBcAg) immunoglobulin $M$ (IgM) anti hepatitis A virus (HAV) IgM, hepatitis $E$ virus (HEV) IgM anti hepatitis $C$ virus (HCV) and HCV-RNA were negative. Antinuclear antibodies (ANAs), anti smooth muscle antibodies (ASMAs), anti mitochondrial (AMA) and anti DNA antibodies were negative. 
Serum alpha1-antitrypsin, ceruloplasmin and ferritin were within normal levels. Results of serologic tests for cytomegalovirus (CMV); and EpsteinBarr virus (EBV), herpes simplex virus (HSV) type 1 and 2, Toxoplasma gondii were negative. Serum gammaglobulin was normal. The patient recovered clinically, serum bilirubin and aminotransferases, ALP returned to normal levels within a 9-week time period (Figure 1).

\section{DISCUSSION}

Several herbal medicines have also been reported to give hepatotoxic effects (4). Estimated percentage of the patients using alternative medications worldwide range from $4 \%$ to $50 \%$ (5). A recent study showed that only $40 \%$ of the people who use herbal medicines have informed their physicians (4). Herbal medicine toxicity has been infrequently reported in Turkey. Germander, a member of the Labiatae family, had been known for more than 2000 years as a herbal remedy and was applied for its assumed choleretic and antiseptic properties (6). T. chamaedrys (germander), which is one of the most common and highly investigated species in the genus, is marketed for use in weight control, but there have been several reports from European countries, especiallly from the Mediterranean area, of hepatotoxity (7) after use of $T$. chameadrys. In our case the patient used T. chameadrys also for weight control. Large-scale usage resulted in a number of reports in 1992 to the French Regional Centers of Pharmacovigilance on cases of germander-associated acute, chronic and even fulminant hepatitis $(2,8)$.

T. chamaedrys has been thoroughly analyzed for its composition and chemical constituents and contains saponins, glycosides, flavonoids and a number of furan-containing neoclerodane diterpenoids (6). While saponins are supposed to be hepatoprotective, furans are well known to be powerful carcinogens to cholangiocellular epithelium as shown in animal models $(1,6)$. Recently, germander hepatotoxicity has been elucidated in animal studies in vivo and in vitro. In a study by Loeper et al. the authors showed that germander is toxic to the liver and that the toxicity is mediated via its furano neoclerodane diterpenoids. The animal experiments, which were performed in mice, proved the formation of toxic metabolites by cytochrome P450 $3 \mathrm{~A}$ and also showed that toxicity is enhanced by induction of cytochrome P450 $3 \mathrm{~A}$ and glutathione depletion (9). Two other cell culture studies raised the hypothesis that germander exerts its detrimental effects to liver cells by inducing apoptosis after the formation of large amounts of reactive metabolites (6). Most affected individuals were women attempting to lose weight, which most probably reflected the high rate of women taking germander rather than gender-specific susceptibility. The daily dosage averaged approximately 600-1600 mg day-1 and hepatitis mostly developed after two months of daily use (10). The clinical picture resembles acute hepatitis with jaundice, markedly elevated transaminases, serum bilirubin levels, and impairment of hepatic synthetic function will occur 3 to 18 weeks after germander administration $(2,6)$. After discontinuing the use of germander, jaundice disappeared within eight weeks and recovery was complete in 1.5 to 6 months. Germander readministration was followed by the prompt recurrence of hepatitis (2). The clinical and laboratory findings in this case of reference 2 were similar to our case. Therefore, cases of herbal medicine toxicitiy might remain unrecognized. Establishing a diagnosis of herbal hepatotoxicity can be difficult. In many instances, herbal hepatotoxins are thought to cause a hypersensitivity or idiosyncratic reaction (4). Liver biopsy specimens showed hepatocyte necrosis (2). Histologically, acute cytolytic hepatitis without characteristic features was detected and some patients with a more benign course of liver disease revealed patterns of chronic hepatitis with fibrosis and even cirrhosis. However, all patients recovered 
after the discontinuation of the use of T. capitatum $L$ except for those with cirrhosis, but relapsed under accidental re-exposure which took place due to the fact that germander had not yet been identified as the etiological toxin (6). The diagnosis of acute hepatitis associated with $T$. chamaedrys ingestion was based on review of the patient's history, clinical findings, laboratory abnormalities, exclusion of other acute hepatitis, the time association between the administration of the herbal tea and onset of symptoms and the fact that, after discontinuation of the herb, the patient improved and progressively recovered completely (11). The toxic effect of the plant suggests, an idiosyncratic adverse reaction to itself (or its metabolites) and may also be the pathogenic basis of the onset of acute hepatitis caused by $T$. chamaedrys in our case. Finally,

\section{REFERENCES}

1. Mallory MA, Lee SW, Kowdley KV. Abnormal liver test results on routine screening: How to evaluate, when to refer for a biopsy. Postgrad Med, 2004; 115: 53-62

2. Stickel F, Egerer G, Seitz HK. Hepatotoxicity of botanicals. Public Health Nutr, 2000; 3: 113-24.

3. Woolf GM, Petrovic LM, Rojter SE, Wainwright S, Villamil FG, Katkov WN et al. Acute hepatitis associated with the Chinese herbal product jin bu huan. Ann Intern Med, 1994; 121: 729-35.

4. Sanders D, Kennedy N, McKendrick MW. Monitoring the safety of herbal remedies. Herbal remedies have a heterogeneous nature. BMJ, 1995; 311: 1569.

5. Larrey D, Vial T, Pauwels A, Castot A, Biour M, David $M$ et al. Hepatitis after germander (Teucrium chamaedrys) administration: another instance of herbal medicine hepatotoxicity. Ann Intern Med, 1992; 117: 165-6.

6. Dourakis SP, Papanikolaou IS, Tzemanakis EN, Hadziyannis SJ. Acute hepatitis associated with herb (Teucrium capitatum L.) administration. Eur J Gastroenterol Hepato, 2002;14:693-5. herbal medicine toxicity incidence may increase due to the growing consumption of these products. Therefore the intake of herbal remedies in patients whose liver tests present abnormalities have to be ruled out.

T. chamaedrys can cause acute icteric hepatitis which might be clinically confused with acute viral hepatitis. This case supports the view that herbal medicines are not always as safe as generally assumed.

\section{ACKNOWLEDGEMENTS}

We are grateful to Osman Tugay for describing this herbal as T. chamaedrys, who is instructor of department of Biology, Faculty of Science and Art, Selcuk University, Konya, Turkey.

7. Bedir E, Manyam R, Khan IA. Neo-clerodane diterpenoids and phenylethanoid glycosides from Teucrium chamaedrys L. Phytochemistry, 2003; 63:977-83.

8. Haller CA, Dyer JE, Ko R, Olson KR. Making a diagnosis of herbal-related toxic hepatitis. West J Med, 2002; 176: 39-44.

9. Loeper J, Descatoire V, Letteron P, Moulis C, Degott $C$, Dansette P et al. Hepatotoxicity of germander in mice. Gastroenterol, 1994; 106: 464-72.

10. Savona G, Garcia-Alvarez MC, Rodriguez B. Dihydroteugin, a neo-clerodane diterpenoid from Teucrium chamaedrys. Phytochemistry, 1982; 21: 721-3

11. Mostefa-Kara N, Pauwels A, Pines E, Biour M, Levy VG. Fatal hepatitis after herbal tea. Lancet, 1992; 340: 674. 


\section{TELIF HAKKI DEVRI / COPYRIGHT RELEASE}

\section{REFIK SAYDAM HIFZISSIHHA MERKEZI BAŞKANLIĞI / REFIK SAYDAM NATIONAL PUBLIC HEALTH AGENCY \\ Türk Hijyen ve Deneysel Biyoloji Dergisi / Turkish Bulletin of Hygiene and Experimental Biology}

$$
\text { .........../20... }
$$

Makale Türü/Article Type:

(...)Araştırma/Research (...)Derleme/Review _...)Olgu Sunumu/Case Report (...)Editöre Mektup/Letter to Editor Makale Başlı̆ı̆/Article Entitled :

Sayın Editör,

Yayınlanması dileğiyle Türk Hijyen ve Deneysel Biyoloji Dergisíne gönderdiğimiz makalenin yazarları olarak;

1. Derginizde yayımlanmak üzere yollamış olduğumuz makalenin orjinal olduğunu; bilimsel ve etik sorumluluğunun bize ait olduğunu,

2. Makalenin; derginizdeki değerlendirme sürecinde başka bir yayın organına yayımlanmak üzere gönderilmediğini ve gönderilmeyeceğini,

3. Makalenin; kişilik ve telif haklarına aykırı kanun dışı maddeler içermediğini,

4. Yayın haklarının Türk Hijyen ve Deneysel Biyoloji Dergisi'ne ait olduğunu kabul ve beyan ederiz.

Dear Editor,

Here, we affirm and warranty as the author(s) of this manuscript submitted to Turkish Bulletin of Hygiene and Experimental Biology that;

1. The article I / We submitted to the Bulletin is original and responsibilities are belong to us ethically and scientifically,

2. The article is not currently being considered for publication by any other journal and will not be submitted for such review while under the evaluation of this bulletin,

3. The article contains no unlawful statements and does not contain any materials that violate any personal or proprietary rights,

4. The article publishing rights belong to Turkish Bulletin of Hygiene and Experimental Biology.

(...)1)

Yazışma Adresi/Corresponding Address :

Tel/Phone :.....

Faks/Fax

İmza/Signature :

(...)2)

e-posta/e-mail

Yazışma Adresi/Corresponding Address

Tel/Phone :.

..Faks/Fax:

Imza/Signature

(...)3) e-posta/e-mail :

Yazışma Adresi/Corresponding Address

Tel/Phone :.....

..Faks/Fax

Imza/Signature :

(...)4) e-posta/e-mail :

Yazışma Adresi/Corresponding Address

Tel/Phone :

.Faks/Fax :

İmza/Signature :

(...)5)

Yazışma Adresi/Corresponding Address

Tel/Phone

..Faks/Fax

e-posta/e-mail :

Not / Note : 1. İletişim kurulacak yazarın yanına $(X)$ işareti koyunuz / Please indicate the corresponding author with (X)

2. Formu aşağıdaki adrese faks/posta yolu ile gönderiniz veya elden teslim ediniz / Please send this form to the address below by faks or mail or deliver personally.

Refik Saydam Hıfzıssıhha Merkezi Başkanlığı / Refik Saydam National Public Health Agency

Türk Hijyen ve Deneysel Biyoloji Dergisi / Turkish Bulletin of Hygiene and Experimental Biology

Yayın ve Dokümantasyon Müdürlüğü / Department of Publication and Documentation

Sağlık Mah. Adnan Saygun Cad. No: $5506100 \quad$ Sihhiye-ANKARA-TURKEY

Tel/Phone : +903124582364Ｆaks/Fax : +903124582408ｅ-posta/e-mail : turkhijyen@rshm.gov.tr 